\title{
Efficacy of coupling gamma irradiation with calcium chloride and lemongrass oil in maintaining guava fruit quality and inhibiting fungal growth during cold storage
}

\author{
Ramadan A. Hassanein ${ }^{1}$, Ehab A. Salem ${ }^{1 *}$, Ahmed A. Zahran ${ }^{2}$ \\ ${ }^{1}$ Food Irradiation Department \\ National Center for Radiation Research and Technology, Atomic Energy Authority \\ 3 Ahmed Al Zumor St., 8th Sector, Madenet Nasr, Cairo, Egypt \\ ${ }^{2}$ Natural Products Research Department \\ National Center for Radiation Research and Technology, Atomic Energy Authority \\ 3 Ahmed Al Zumor St., 8th Sector, Madenet Nasr, Cairo, Egypt
}

\begin{abstract}
This study was performed to explore the efficacy of combining more than one postharvest treatment in maintaining some quality attributes and reducing fungal pathogenicity in cold-stored guava fruits. The investigated postharvest treatments included the control, $\mathrm{CaCl}_{2}(4 \%)$, lemongrass oil $\left(2 \mathrm{dm}^{3} \mathrm{~kg}^{-1}\right)$, gamma $(\gamma)$ irradiation $(0.2,0.4$ and $0.6 \mathrm{kGy}), 0.4 \mathrm{kGy} \gamma$ irradiation $+\mathrm{CaCl}_{2}(4 \%)$, and $0.4 \mathrm{kGy} \gamma$ irradiation + lemongrass oil $\left(2 \mathrm{dm}^{3} \mathrm{~kg}^{-1}\right)$. The studied physiochemical attributes included weight loss, decay percentage, fruit firmness, total soluble solids (TSS), titratable acidity (TA), and vitamin C content. Different fungal species were also isolated from decayed fruits and were identified as Alternaria alternata, Alternaria solani, Aspergillus niger, Botrytis cinerea, Fusarium solani and Rhizopus stolonifer. The severity of infection for the different fungi was determined, and an in vitro antifungal assay was conducted for lemongrass oil. All the investigated treatments generally reduced decay and water loss percentages, and controlled TSS, TA and vitamin C decrements that occurred during cold storage. On the other hand, higher irradiation doses generally increased fruit softness, and the $0.4 \mathrm{kGy} \gamma$ dose did not contribute to the overall fruit quality when coupled with $\mathrm{CaCl}_{2}$ and lemongrass oil, compared to $\mathrm{CaCl}_{2}$ and lemongrass oil treatments alone.
\end{abstract}

Keywords: cold storage, fungal growth, postharvest, Psidium guajava L.

\section{INTRODUCTION}

Guava (Psidium guajava L.) is a widely-grown fruit in tropical and subtropical regions that belongs to the family Myrtaceae. It is regarded as a "super fruit" due to its remarkable nutritional value and numerous health-promoting qualities (Razali et al., 2015). Moreover, guava is commercially rewarding even without much care (Negi and Rajan, 2007). Improper postharvest handling and microbial attacks account for $25-40 \%$ of the harvested guava fruit loss (Pandey et al., 2010). Unfortunately, long-term use of fungicides to reduce postharvest losses caused by pathogenic fungi have resulted in several concerns such as development of fungicideresistant strains of fungi, environmental pollution and human health problems (Shahi et al., 2003; Antunes and Cavaco, 2010). That is why there is interest in developing safe, applicable, low-cost 
postharvest protocols aiming to extend the shelflife of this perishable climacteric fresh produce and maintain its quality above consumer standards. Such approaches improve supply chain efficiency, widen export prospects, enhance profitability, and contribute to the fulfilment of market needs with regard to quantity and quality.

Unlike ambient conditions in which guava fruits become overripe and mealy within a week, refrigerated storage maintains the quality of most fruits by reducing disease incidence and slowing down enzymatic reactions and physiological activity, and thus delays ripening and senescence, and extends shelf-life (Bron et al., 2005). Postharvest applications of calcium salts also extend the shelf-life of many fruits by maintaining firmness and minimizing respiration rate, protein breakdown and disease incidence. Moreover, this practice has proved to be useful for retaining the quality of guava fruits (Hiwale and Singh, 2003; Selvan and Bal, 2005). Calcium salts can also reduce pathogen spore germination, sporulation and growth, and form complexes with plant cell walls, which improves structural integrity, retards tissue softening and delays ripening (Silva et al., 2012; Cruz et al., 2015). It is also well known that ionizing radiation reduces microbial load and thus prolongs fruit and vegetable shelf-life (Pandey et al., 2010). Essential oils (EOs) have also been reported to extend the shelf-life of fruits (Abd-Alla et al., 2008; Garcia et al., 2008) and fruit juices (Tserennadmid et al., 2011). The advantages of EOs also include their versatile uses, non-toxic nature and wide acceptance by consumers (Antunes and Cavaco, 2010). EOs are plant-derived volatiles with a hydrophobic nature, which are known to possess antiviral, antibacterial, antifungal and insecticidal properties (Burt, 2004). Lemongrass (Cymbopogon citratus) oil is one of the widely used EOs that has been granted a GRAS (generally regarded as safe) status (Palhano et al., 2004). Although the chemical composition of lemongrass essential oil varies according to genetic diversity, habitat and agronomic treatments (Paviani et al., 2006), its leaves are characterized by its main constituent, citral, which is a combination of neral and geranial isomers (Carlson et al., 2001). Tzortzakis and Economakis (2007) reported that lemongrass oil has potential in limiting pathogen spread by lowering the spore load in storage/transit atmospheres as well as in being used as an alternative food preservative.

In this study, ionizing radiation was combined with other widely used environmentally friendly compounds as postharvest treatments to evaluate the efficacy of combining those treatments in extending the shelf-life of the guava fruit and maintaining its quality during cold storage.

\section{MATERIAL AND METHODS}

\section{Sample collection and preparation}

This investigation was conducted during the 2014 and 2015 seasons. 'Baladi' guava fruits were harvested at commercial maturity (yellowish green) from an orchard located in Al-Salhiya, Al-Sharquia Governorate, and transported immediately to the Postharvest Laboratory in the National Center for Radiation Research and Technology (NCRRT), Cairo, Egypt. Defective fruits were discarded, and only intact, physically sound fruits of uniform size and colour were selected, rinsed in tap water and air-dried. For each of the following treatments, 150 fruits were divided equally into 6 cartons (replicates), three of which were used for nondestructive determinations and the other three were used for destructive determinations.

\section{Treatments}

The treatments were as follows: (1) Control: 5 min. soak in tap water; (2) $\mathrm{CaCl}_{2}: 5 \mathrm{~min}$. soak in $4 \% \mathrm{CaCl}_{2}$ solution; (3) Lemongrass oil: crude lemongrass oil at a concentration of $2 \mathrm{dm}^{3} \mathrm{~kg}^{-1}$ fresh fruit was administered to four filter papers that were stapled to the four inner corners of the carton cover immediately before cold storage; the lemongrass oil was obtained from SEKEM Company, Cairo, Egypt; (4) $0.2 \mathrm{kGy} \gamma$ irradiation; (5) $0.4 \mathrm{kGy} \gamma$ irradiation; (6) $0.6 \mathrm{kGy} \gamma$ irradiation; (7) $0.4 \mathrm{kGy} \gamma$ irradiation followed by $4 \% \mathrm{CaCl}_{2}$ application; (8) $0.4 \mathrm{kGy} \gamma$ irradiation followed by lemongrass oil $\left(2 \mathrm{dm}^{3} \mathrm{~kg}^{-1}\right.$ fresh fruit) application.

Fruit irradiation was performed at dose rates of 2.35 and $2.06 \mathrm{kGy} \mathrm{h}^{-1}$ in the 2014 and 2015 seasons, respectively, in NCRRT, using a self-contained dry-storage gamma irradiator (Indian gamma cell GE $4000 \mathrm{~A}$ ) that uses ${ }^{60} \mathrm{Co}$ as a radiation source. Afterwards, the fruits were divided and stored in three refrigerators (one replicate or block per refrigerator) at a temperature of $8 \pm 1^{\circ} \mathrm{C}$ and $90 \%$ relative humidity for 20 days, during which physiochemical determinations were conducted regularly every 5 days.

\section{Physiochemical determinations}

The initial fruit quality evaluation was conducted immediately before treatments and cold storage. Juice samples required for the physiochemical 
evaluations were manually extracted from the fruits using hand pressure and filtration through cheesecloth.

Fruit firmness was measured using a MagnessTaylor penetrometer (pressure tester) with a standard 5/16-inch plunger. Readings were taken in two positions on each tested fruit, averaged and recorded in $\mathrm{lb}$ inch $^{-2}$ prior to mathematical conversion to $\mathrm{kPa}$.

Weight loss (\%) was determined according to equation 1 .

Weight loss $(\%)=\frac{\text { Fruit initial weight }- \text { Fruit weight on sampling date }}{\text { Fruit initial weight }} \times 100$

Fruit decay (\%): All unmarketable fruits were considered as decayed, and decay percentage was calculated according to equation 2 .

$$
\text { Decay }(\%)=\frac{a}{b} \times 100
$$

$a=$ number of decayed fruits at time of sampling, and $b=$ initial number of stored fruits

Total soluble solids (TSS) content (\%) was determined in the juice directly extracted from fruits, with a Carl Zeiss hand refractometer (AOAC 2003).

Titratable acidity (TA) (\%) was expressed as a percentage of citric acid and calculated as described in AOAC (1990) using equation 3.

$$
\mathrm{TA} \%=\frac{\mathrm{mL} \text { of } \mathrm{NaOH} \times \text { Normality } \times 0.067}{\mathrm{~mL} \text { juice used }} \times 100
$$

Vitamin $\mathrm{C}$ content was determined and expressed in $\mathrm{mg}$ ascorbic acid per $100 \mathrm{~g}$ fresh weight (FW) of fruit according to AOAC (1990).

\section{Microbiological studies}

At the end of the storage period in the 2014 season, decayed fruits from each treatment showing symptoms of rotting were surface-sterilized with absolute ethanol and rinsed twice in sterile distilled water. Rotten portions of these fruits were cut off with sterilized scalpels, homogenized using a sterilized laboratory blender and immediately transferred into sterile conical flasks, which were then wrapped tightly and stored under aseptic conditions for further use (Balali et al., 1995). The medium used for fungal isolation in this study was fresh Potato Dextrose Agar (PDA, Merck KGaA, Darmstadt, Germany) supplemented with $30 \mathrm{mg} \mathrm{dm}^{-3}$ chloramphenicol to prevent bacterial contamination (Adamu et al., 2009). Twenty $\mathrm{dm}^{3}$ of sterile liquid medium was poured into Petri dishes that were inoculated afterwards with $1 \mathrm{dm}^{3}$ of different dilutions of homogenized guava pulp, which was spread evenly over the surface of the medium (Pelczar, 1993). The inoculated plates were incubated at $25^{\circ} \mathrm{C}$ for a week, during which they were observed daily. The observed colony development was continuously re-isolated promptly onto PDA slants to maintain pathogenicity of the inocula. Identification of the fungal isolates was carried out by microscopic observation according to the appropriate taxonomic key and description (Booth, 1977; Raper and Fennell, 1977; Domsch et al., 1980; Moubasher, 1993) in Mycological Laboratory 2 (ML 2), Faculty of Science, Zagazig University.

The pathogenicity test was carried out for the fungal isolates identified in this study. Freshly harvested healthy guava fruits were rinsed in sterile water, air-dried at room temperature, then surface-sterilized using $80 \%$ ethanol. Afterwards, the fruits were wounded by making holes in them using sterile $5 \mathrm{~mm}$-diameter cork borers and inoculated with mycelial discs of the same size cut out from pure culture plates of the isolates and plugged into the holes made in the fruits. Control fruits were inoculated with sterile PDA plugs. All the inoculated fruits were put into sterilized carton boxes and incubated at room temperature $(28 \pm$ $2^{\circ} \mathrm{C}$ ). The severity of infection was calculated after 5 and 10 days according to equation 4 , as described by Morcos (1984). For each fungus, three replicates/ cartons, each containing 5 inoculated fruits, were tested.

$$
\text { Severity of infection }=\frac{\text { External rotten area of a fruit }}{\text { Total area of the same fruit }} \times 100 \quad \text { (4) }
$$

Based on the inhibition in radial mycelial growth and conidial germination of all the isolated pathogenic fungi cultured on PDA, an antifungal assay of lemongrass oil using the poison food technique was conducted. A 5-mm agar disc from a pure culture of each fungus was placed in the centre of a PDA plate containing different concentrations of lemongrass oil [0.0 (control), 0.5 , $\left.1.0,1.5,2.0,2.5,3.0,3.5,4.0 \mu \mathrm{g} \mathrm{dm}^{-3}\right]$ dissolved in $1 \%$ Tween 80 as an emulsifying agent. Growth measurements were taken when the control plates had reached full growth (fungus had reached plate edge) at $25^{\circ} \mathrm{C}$. For each treatment, 9 plates were prepared, among which each 3 represented a replicate.

\section{Statistical analysis}

The experiment was laid out using a Completely Randomized Block Design (CRBD). Three replicates per treatment were evaluated for fruit quality attributes. The experimental data obtained 
was subjected to analysis of variance (ANOVA) at a confidence level of $95 \%$, which is the procedure used for testing the differences among means of two or more treatments, and the differences between means were detected using least significant difference (LSD) at $p<0.05$. All data was analyzed using statistical software (MSTATC 2.10, Russell D. Freed).

\section{RESULTS AND DISCUSSION}

\section{Weight loss}

The results presented in Table 1 show that all stored guava fruits recorded weight loss at the end of the storage period. Similar results have been reported for guava (Hossain et al., 2014) and several other fruits and vegetables (Orathai and Lih-Shang, 2012; Geransayeh et al., 2015). In this regard, Munoz et al. (2008) stated that the rate at which water is lost depends on the water pressure gradient between fruit tissue and the surrounding atmosphere, and on the storage temperature. Alves et al. (2004) also reported that increased weight loss is caused by increased metabolic activity and moisture evaporation through the skin. In agreement with the results by Hossain et al. (2014), we also found that the radiation treatments reduced water loss compared to the control and maintained marketability of the fruits throughout the whole storage period. Our results also reveal that the lemongrass oil treatments were useful in controlling weight loss. This agrees with the results by Serrano et al. (2005), who found that applications of EOs significantly decreased weight loss percentage in cherries and grapes. Similarly, Tian et al. (2011) reported reduced weight loss and significantly increased shelf-life of strawberry and tomato fruits in response to eucalyptus and cinnamon oil treatments. Jhalegar et al. (2015) attributed the efficacy of EOs in decreasing weight loss to reduced rates of respiration and ethylene production, which might have inhibited water loss from fruits. In this regard, Mahajan et al. (2009) reported that fruits became shrivelled and unmarketable if weight loss during storage exceeded 5\%. Finally, $\mathrm{CaCl}_{2}$ treatments also reduced water loss from the stored guava fruits compared to the control. Taking this into consideration makes all the investigated treatments beneficial in this regard compared to the untreated (control) fruits. Limiting weight loss in guava fruits during cold storage with the aid of $\mathrm{CaCl}_{2}$ treatments had been previously reported by Mahajan et al. (2011) and Deepthi et al. (2016). The success of the treatment is probably attributed to its effectiveness in maintaining membrane functionality and integrity, and thus in reducing losses of phospholipids and proteins and ion leakage (Lester and Grusak 2004). Finally, it is worth mentioning that although the irradiation treatments reduced water loss, coupling them with $\mathrm{CaCl}_{2}$ and lemongrass oil was of no added value in terms of fruit moisture retention.

\section{Decay}

The results presented in Table 2 show that the earliest incidence of decay was recorded for the untreated (control) fruits after 10 days of cold storage and was of statistical significance in the 2015 season only. With continued storage, further decay was recorded for the control fruits in both experimental seasons. On the other hand, the treatments incorporating $\mathrm{CaCl}_{2}$ or lemongrass oil, or $0.6 \mathrm{kGy} \gamma$ irradiation totally eradicated decay throughout the whole storage period. It was also noticed that $0.2 \mathrm{kGy} \gamma$-treated fruits started to show a slight decay percentage after 15 days of cold

Table 1. Effect of postharvest treatments on guava fruit weight loss (\%) during cold storage

\begin{tabular}{|c|c|c|c|c|c|c|c|c|}
\hline \multirow{2}{*}{ Treatments } & \multicolumn{4}{|c|}{ Storage period 2014} & \multicolumn{4}{|c|}{ Storage period 2015} \\
\hline & 5 days & 10 days & 15 days & 20 days & 5 days & 10 days & 15 days & 20 days \\
\hline Control & $0.79 \mathrm{a}$ & $1.99 \mathrm{a}$ & $4.90 \mathrm{a}$ & $5.77 \mathrm{a}$ & $0.93 \mathrm{ab}$ & $2.22 \mathrm{a}$ & $4.67 \mathrm{a}$ & $6.03 \mathrm{a}$ \\
\hline $\mathrm{CaCl}_{2}(4 \%)$ & $0.56 \mathrm{c}$ & $1.11 \mathrm{c}$ & $3.05 \mathrm{c}$ & $3.51 \mathrm{c}$ & $0.73 \mathrm{~d}$ & $1.32 \mathrm{~d}$ & $3.24 \mathrm{c}$ & $3.66 \mathrm{de}$ \\
\hline C. citratus EO $\left(2 \mathrm{dm}^{3} \mathrm{~kg}^{-1}\right)$ & $0.63 \mathrm{bc}$ & $1.50 \mathrm{~b}$ & $3.83 \mathrm{~b}$ & $4.00 \mathrm{bc}$ & $0.92 \mathrm{ab}$ & $1.74 \mathrm{bc}$ & $3.42 \mathrm{bc}$ & $4.51 \mathrm{bcd}$ \\
\hline $0.2 \mathrm{kGy} \gamma$ & $0.66 \mathrm{bc}$ & $1.20 \mathrm{c}$ & $3.76 \mathrm{~b}$ & $3.95 \mathrm{bc}$ & $0.90 \mathrm{ab}$ & $1.68 \mathrm{bc}$ & $3.21 \mathrm{c}$ & $4.43 \mathrm{bcd}$ \\
\hline $0.4 \mathrm{kGy} \gamma$ & $0.73 \mathrm{ab}$ & $1.50 \mathrm{~b}$ & $3.82 \mathrm{~b}$ & $4.08 \mathrm{bc}$ & $0.87 \mathrm{bc}$ & $1.60 \mathrm{bcd}$ & $3.46 \mathrm{bc}$ & $4.69 \mathrm{bc}$ \\
\hline $0.6 \mathrm{kGy} \gamma$ & $0.80 \mathrm{a}$ & $1.95 \mathrm{a}$ & $3.91 \mathrm{~b}$ & $4.28 \mathrm{~b}$ & $1.01 \mathrm{a}$ & $1.85 \mathrm{~b}$ & $3.99 \mathrm{ab}$ & $5.03 \mathrm{~b}$ \\
\hline $0.4 \mathrm{kGy} \gamma+\mathrm{CaCl}_{2}(4 \%)$ & $0.55 \mathrm{c}$ & $1.01 \mathrm{c}$ & $3.00 \mathrm{c}$ & $3.48 \mathrm{c}$ & $0.74 \mathrm{~cd}$ & $1.33 \mathrm{~d}$ & $3.01 \mathrm{c}$ & $3.48 \mathrm{e}$ \\
\hline $\begin{array}{l}0.4 \mathrm{kGy} \gamma+ \\
\text { C. citratus } \mathrm{EO}\left(2 \mathrm{dm}^{3} \mathrm{~kg}^{-1}\right)\end{array}$ & $0.59 \mathrm{c}$ & $1.19 \mathrm{c}$ & $3.11 \mathrm{c}$ & $3.83 \mathrm{bc}$ & $0.85 \mathrm{bcd}$ & $1.44 \mathrm{~cd}$ & $3.55 \mathrm{bc}$ & 4.12 cde \\
\hline
\end{tabular}

Means bearing the same letter within a column are not significantly different at $p<0.05$ 
Table 2. Effect of postharvest treatments on guava fruit decay percentage during cold storage

\begin{tabular}{lcccccccc}
\hline \multirow{2}{*}{ Treatments } & \multicolumn{3}{c}{ Storage period 2014} & \multicolumn{5}{c}{ Storage period 2015} \\
& 5 days & 10 days & 15 days & 20 days & 5 days & 10 days & 15 days & 20 days \\
\hline Control & 0.00 & 1.33 & $2.67 \mathrm{a}$ & $8.00 \mathrm{a}$ & 0.00 & $2.67 \mathrm{a}$ & $4.00 \mathrm{a}$ & $9.33 \mathrm{a}$ \\
$\mathrm{CaCl}_{2}(4 \%)$ & 0.00 & 0.00 & $0.00 \mathrm{~b}$ & $0.00 \mathrm{~b}$ & 0.00 & $0.00 \mathrm{~b}$ & $0.00 \mathrm{~b}$ & $0.00 \mathrm{c}$ \\
C. citratus EO $\left(2 \mathrm{dm}^{3} \mathrm{~kg}^{-1}\right)$ & 0.00 & 0.00 & $0.00 \mathrm{~b}$ & $0.00 \mathrm{~b}$ & 0.00 & $0.00 \mathrm{~b}$ & $0.00 \mathrm{~b}$ & $0.00 \mathrm{c}$ \\
$0.2 \mathrm{kGy} \gamma$ & 0.00 & 0.00 & $1.33 \mathrm{ab}$ & $2.67 \mathrm{~b}$ & 0.00 & $0.00 \mathrm{~b}$ & $2.67 \mathrm{a}$ & $4.00 \mathrm{~b}$ \\
$0.4 \mathrm{kGy} \gamma$ & 0.00 & 0.00 & $0.00 \mathrm{a}$ & $1.33 \mathrm{~b}$ & 0.00 & $0.00 \mathrm{~b}$ & $0.00 \mathrm{~b}$ & $0.00 \mathrm{c}$ \\
$0.6 \mathrm{kGy} \gamma$ & 0.00 & 0.00 & $0.00 \mathrm{~b}$ & $0.00 \mathrm{~b}$ & 0.00 & $0.00 \mathrm{~b}$ & $0.00 \mathrm{~b}$ & $0.00 \mathrm{c}$ \\
$0.4 \mathrm{kGy} \gamma+\mathrm{CaCl}_{2}(4 \%)$ & 0.00 & 0.00 & $0.00 \mathrm{~b}$ & $0.00 \mathrm{~b}$ & 0.00 & $0.00 \mathrm{~b}$ & $0.00 \mathrm{~b}$ & $0.00 \mathrm{c}$ \\
$0.4 \mathrm{kGy} \gamma+$ & 0.00 & 0.00 & $0.00 \mathrm{~b}$ & $0.00 \mathrm{~b}$ & 0.00 & $0.00 \mathrm{~b}$ & $0.00 \mathrm{~b}$ & $0.00 \mathrm{c}$ \\
C. citratus $\mathrm{EO}\left(2 \mathrm{dm}^{3} \mathrm{~kg}^{-1}\right)$ & & & & & &
\end{tabular}

Means bearing the same letter/no letters within a column are not significantly different at $p<0.05$

Table 3. Effect of postharvest treatments on guava fruit firmness $(\mathrm{kPa})$ during cold storage

\begin{tabular}{|c|c|c|c|c|c|c|c|c|c|c|}
\hline \multirow{2}{*}{ Treatments } & \multicolumn{5}{|c|}{ Storage period 2014} & \multicolumn{5}{|c|}{ Storage period 2015} \\
\hline & 0 days & 5 days & 10 days & 15 days & 20 days & 0 days & 5 days & 10 days & 15 days & 20 days \\
\hline Control & 61.36 & 48.95 & 48.26 & $29.65 \mathrm{~b}$ & $23.44 \mathrm{~b}$ & 59.29 & $48.95 \mathrm{ab}$ & $42.06 \mathrm{ab}$ & $28.96 \mathrm{~b}$ & $21.37 \mathrm{bc}$ \\
\hline $\mathrm{CaCl}_{2}(4 \%)$ & & 55.85 & 48.26 & $36.54 \mathrm{a}$ & $28.27 \mathrm{a}$ & & $54.47 \mathrm{a}$ & $48.95 \mathrm{a}$ & $36.54 \mathrm{a}$ & $28.96 \mathrm{a}$ \\
\hline C. citratus $\mathrm{EO}\left(2 \mathrm{dm}^{3} \mathrm{~kg}^{-1}\right)$ & & 55.16 & 48.26 & $33.78 \mathrm{ab}$ & $27.58 \mathrm{a}$ & & $51.71 \mathrm{ab}$ & $47.57 \mathrm{ab}$ & $28.27 \mathrm{~b}$ & $23.44 \mathrm{~b}$ \\
\hline $0.2 \mathrm{kGy} \gamma$ & & 55.16 & 48.26 & $30.34 \mathrm{~b}$ & $27.58 \mathrm{a}$ & & $49.64 \mathrm{ab}$ & $44.82 \mathrm{ab}$ & $26.89 \mathrm{bc}$ & $21.37 \mathrm{bc}$ \\
\hline $0.4 \mathrm{kGy} \gamma$ & & 52.40 & 42.06 & $28.96 \mathrm{~b}$ & $20.68 \mathrm{~b}$ & & $46.88 \mathrm{ab}$ & $42.06 \mathrm{ab}$ & $25.51 b c$ & $20.68 \mathrm{bc}$ \\
\hline $0.6 \mathrm{kGy} \gamma$ & & 48.95 & 41.37 & $21.37 \mathrm{c}$ & $14.48 \mathrm{c}$ & & $46.19 \mathrm{~b}$ & $40.68 \mathrm{~b}$ & $22.06 \mathrm{c}$ & $18.62 \mathrm{c}$ \\
\hline $0.4 \mathrm{kGy} \gamma+\mathrm{CaCl}_{2}(4 \%)$ & & 55.16 & 48.26 & $34.47 \mathrm{ab}$ & $30.34 \mathrm{a}$ & & $54.47 \mathrm{ab}$ & $46.88 \mathrm{ab}$ & $35.85 \mathrm{a}$ & $28.27 \mathrm{a}$ \\
\hline $\begin{array}{l}0.4 \mathrm{kGy} \gamma+ \\
\text { C. citratus } \mathrm{EO}\left(2 \mathrm{dm}^{3} \mathrm{~kg}^{-1}\right)\end{array}$ & & 55.16 & 48.26 & $34.47 \mathrm{ab}$ & $27.58 \mathrm{a}$ & & $51.02 \mathrm{ab}$ & $44.13 \mathrm{ab}$ & $29.65 b$ & $22.75 \mathrm{bc}$ \\
\hline
\end{tabular}

Means bearing the same letter/no letters within a column are not significantly different at $p<0.05$

storage in both experimental seasons. Our results regarding the effect of $\gamma$ irradiation on decay are in agreement with the results of Hossain et al. (2014), who reported that irradiating guava fruits prior to storage delayed ripening and prevented decay for 19 days in cold storage. Moreover, it is worth mentioning that EOs in the vapour state are more effective in exerting their antifungal and antimicrobial control than their liquid phases (Tyagi and Malik, 2010), thus reducing decay, which agrees with our results. This is possibly due to the better attachment of oil molecules in the vapour phase to the lipophilic fungal mycelia, compared with the liquid phase (Inouye et al., 2000). And finally, Mahajan et al. (2011) reported that postharvest application of $\mathrm{CaCl}_{2}$ extended storage life of guava fruits and reduced spoilage and attributed that to its positive role in delaying fruit senescence by maintaining cell wall integrity and thus reducing decay.

\section{Fruit firmness}

As presented in Table 3, guava fruit firmness dropped with the duration of storage. Similar results have been reported for guava (Razali et al., 2015) and other climacteric fruits such as mangos (Abd ElMonem et al., 2013). This effect can be attributed to increased solubilisation of pectins during ripening (Jovyn et al., 2015). In this regard, Celestino et al. (2016) partially attributed mango fruit softness to pectinesterase and polygalacturonase activities in the mesocarp of the fruit. Paliyath et al. (2008) confirmed such results by stating that events that occurred during ripening and senescence reflected the deterioration of cellular structures and, in particular, of the cell membrane. This degradation and quality loss are enhanced by Reactive Oxygen Species (ROS) produced in response to different kinds of stresses that occur before and after harvest, which in turn cause oxidative damage (Valenzuela et al., 2017). This may explain the relatively reduced firmness recorded for irradiated fruits. In contrast, lemongrass oil played a positive role in maintaining guava fruit firmness during storage. Its effect can be due to the previously mentioned role of EOs in reducing respiration rate and ethylene production, and hence deterioration (Jhalegar et al., 2015). 
On the other hand, postharvest $\mathrm{CaCl}_{2}$ treatments reduced the softness of guava fruits during storage, which is a result similar to that reported by Mahajan et al. (2011) for guava. The positive effect of $\mathrm{CaCl}_{2}$ on fruit firmness might be attributed to the possible role of $\mathrm{Ca}^{2+}$ in the bridging of anti-parallel pectic polysaccharide homogalacturonan ( $\mathrm{HG})$, which plays a vital role in maintaining cell wall integrity and cell-wall cohesion, with negatively charged carboxyl groups (Lionetti et al., 2010). The positive effect of calcium may also be explained by its role in reducing the accessibility of cell wall-degrading enzymes to cell wall component substrates (Vicente et al., 2009). In this regard, it is worth mentioning that Akhtar et al. (2010) and Gupta et al. (2011) reported that higher $\mathrm{CaCl}_{2}$ concentrations retained firmness more than its lower concentrations.

\section{TSS}

The results presented in Table 4 show that TSS increased in all treatments as storage progressed until the 10th day, after which decreases were recorded. Mahajan et al. (2011) and Deepthi et al. (2016) confirmed this trend followed by TSS in guava fruits during cold storage. Our result also agrees with the findings of Pandey et al. (2010), who found that physiochemical parameters increased in stored guava fruits for up to 8 days. TSS increases have also been reported for other fruits such as mango and strawberry (Abd El-Monem et al., 2013; Geransayeh et al., 2015). The detected increases in TSS are possibly due to the increased activity of starch hydrolyzing enzymes (Zhong and Xia, 2007), while the subsequent decline in TSS is probably because sugars (main contributor to TSS) are consumed along with other organic acids as substrates in the respiration process (Ball, 1997). The role of $\mathrm{CaCl}_{2}$ in controlling the TSS drops found in this study can be confirmed by the findings of Deepthi et al. (2016) and might be due to its role in delaying metabolic activity in fruits during storage. This is in agreement with increased levels of TSS reported in response to respiration inhibiting treatments (Yonemoto et al., 2002). It was also found that lemongrass oil controlled the decline in TSS, and this might be indirectly attributed to its inhibitory effect on respiration and other bioactivities that consume sugars, which are the main constituent of TSS. Finally, no consistent trend was noticed for the effect of irradiation on TSS, although its role was negligible in controlling the reductions in TSS. Moreover, coupling irradiation with $\mathrm{CaCl}_{2}$ and lemongrass oil slightly reduced their effect in controlling those reductions.

\section{$\boldsymbol{T A}$}

As shown in Table 5, all the investigated treatments produced increments in TA until the 5th day, after which TA decrements were recorded. Lemongrass oil played a positive role in retaining TA, and this might be due to the delayed ripening imposed by the EO. This result agrees with the results reported by Hossain et al. (2014), who found that TA in guava fruits increased for a few days until the ripening peak before it started to decrease towards the end of the storage period. The TA reduction control in the lemongrass oil-treated fruits might be attributed to its role in inhibiting respiration and other physiological activities in fruits (Jhalegar et al., 2015), and hence ripening. General reduction in TA during storage has also been reported for other fruits such as pineapple (Ibrahim et al., 2014). The controlled TA reduction detected in this trial in response to lemongrass EO is in accordance with the results reported for thymol-treated strawberry (Geransayeh et al., 2015). The decrements in TA

Table 4. Effect of postharvest treatments on total soluble solids (\%) in guava fruits during cold storage

\begin{tabular}{|c|c|c|c|c|c|c|c|c|c|c|}
\hline \multirow{2}{*}{ Treatments } & \multicolumn{5}{|c|}{ Storage period 2014} & \multicolumn{5}{|c|}{ Storage period 2015} \\
\hline & 0 days & 5 days & 10 days & 15 days & 20 days & 0 days & 5 days & 10 days & 15 days & 20 days \\
\hline Control & 11.23 & 12.03 & 12.62 & 11.56 & 10.24 & 11.14 & 12.63 & 13.25 & 12.14 & $10.75 \mathrm{ab}$ \\
\hline $\mathrm{CaCl}_{2}(4 \%)$ & & 11.82 & 12.22 & 11.87 & 11.06 & & 12.29 & 12.71 & 12.34 & $11.50 \mathrm{a}$ \\
\hline C. citratus EO $\left(2 \mathrm{dm}^{3} \mathrm{~kg}^{-1}\right)$ & & 11.27 & 12.11 & 11.72 & 11.44 & & 11.61 & 12.47 & 12.07 & $11.78 \mathrm{a}$ \\
\hline $0.2 \mathrm{kGy} \gamma$ & & 12.02 & 12.70 & 11.80 & 10.77 & & 12.50 & 13.21 & 12.27 & $11.20 \mathrm{ab}$ \\
\hline $0.4 \mathrm{kGy} \gamma$ & & 12.33 & 12.92 & 11.83 & 10.52 & & 11.86 & 12.45 & 11.38 & $10.11 \mathrm{ab}$ \\
\hline $0.6 \mathrm{kGy} \gamma$ & & 12.50 & 13.02 & 11.65 & 10.08 & & 13.13 & 13.67 & 11.07 & $9.58 \mathrm{~b}$ \\
\hline $0.4 \mathrm{kGy} \gamma+\mathrm{CaCl}_{2}(4 \%)$ & & 11.45 & 12.12 & 11.34 & 10.88 & & 11.91 & 12.61 & 11.78 & $11.13 \mathrm{ab}$ \\
\hline $\begin{array}{l}0.4 \mathrm{kGy} \gamma+ \\
\text { C. citratus } \mathrm{EO}\left(2 \mathrm{dm}^{3} \mathrm{~kg}^{-1}\right)\end{array}$ & & 11.90 & 12.36 & 11.60 & 10.85 & & 12.26 & 12.73 & 12.53 & $11.76 \mathrm{a}$ \\
\hline
\end{tabular}

Means bearing the same letter/no letters within a column are not significantly different at $p<0.05$ 
Table 5. Effect of postharvest treatments on titratable acidity (\%) in guava fruits during cold storage

\begin{tabular}{|c|c|c|c|c|c|c|c|c|c|c|}
\hline \multirow{2}{*}{ Treatments } & \multicolumn{5}{|c|}{ Storage period 2014} & \multicolumn{5}{|c|}{ Storage period 2015} \\
\hline & 0 days & 5 days & 10 days & 15 days & 20 days & 0 days & 5 days & 10 days & 15 days & 20 days \\
\hline Control & 0.32 & 0.35 & 0.33 & $0.28 \mathrm{c}$ & $0.22 \mathrm{c}$ & 0.30 & 0.34 & 0.30 & $0.25 \mathrm{~b}$ & $0.20 \mathrm{c}$ \\
\hline $\mathrm{CaCl}_{2}(4 \%)$ & & 0.34 & 0.34 & $0.31 \mathrm{a}$ & $0.26 \mathrm{~b}$ & & 0.33 & 0.31 & $0.28 \mathrm{a}$ & $0.25 \mathrm{a}$ \\
\hline C. citratus EO $\left(2 \mathrm{dm}^{3} \mathrm{~kg}^{-1}\right)$ & & 0.34 & 0.34 & $0.31 \mathrm{a}$ & $0.28 \mathrm{a}$ & & 0.33 & 0.31 & $0.29 \mathrm{a}$ & $0.25 \mathrm{a}$ \\
\hline $0.2 \mathrm{kGy} \gamma$ & & 0.34 & 0.33 & $0.30 \mathrm{ab}$ & $0.23 \mathrm{c}$ & & 0.33 & 0.31 & $0.28 \mathrm{a}$ & $0.25 \mathrm{a}$ \\
\hline $0.4 \mathrm{kGy} \gamma$ & & 0.34 & 0.33 & $0.30 \mathrm{abc}$ & $0.23 \mathrm{c}$ & & 0.34 & 0.30 & $0.26 \mathrm{~b}$ & $0.24 \mathrm{ab}$ \\
\hline $0.6 \mathrm{kGy} \gamma$ & & 0.35 & 0.33 & $0.29 \mathrm{bc}$ & $0.22 \mathrm{c}$ & & 0.34 & 0.30 & $0.25 \mathrm{~b}$ & $0.23 \mathrm{~b}$ \\
\hline $0.4 \mathrm{kGy} \gamma+\mathrm{CaCl}_{2}(4 \%)$ & & 0.34 & 0.33 & $0.31 \mathrm{a}$ & $0.26 \mathrm{~b}$ & & 0.33 & 0.31 & $0.28 \mathrm{a}$ & $0.25 \mathrm{a}$ \\
\hline $\begin{array}{l}0.4 \mathrm{kGy} \gamma+ \\
\text { C. citratus } \mathrm{EO}\left(2 \mathrm{dm}^{3} \mathrm{~kg}^{-1}\right)\end{array}$ & & 0.34 & 0.33 & $0.30 \mathrm{ab}$ & $0.27 \mathrm{ab}$ & & 0.33 & 0.31 & $0.28 \mathrm{a}$ & $0.25 \mathrm{a}$ \\
\hline
\end{tabular}

Means bearing the same letter/no letters within a column are not significantly different at $p<0.05$

Table 6. Effect of postharvest treatments on guava vitamin $\mathrm{C}$ content (mg $100 \mathrm{~g}^{-1} \mathrm{FW}$ ) during cold storage

\begin{tabular}{|c|c|c|c|c|c|c|c|c|c|c|}
\hline \multirow{2}{*}{ Treatments } & \multicolumn{5}{|c|}{ Storage period 2014} & \multicolumn{5}{|c|}{ Storage period 2015} \\
\hline & 0 days & 5 days & 10 days & 15 days & 20 days & 0 days & 5 days & 10 days & 15 days & 20 days \\
\hline Control & 193.8 & 192.5 & 175.9 & 132.8 & 88.0 & 198.9 & 201.5 & 180.7 & $130.6 \mathrm{~b}$ & $101.8 \mathrm{~b}$ \\
\hline $\mathrm{CaCl}_{2}(4 \%)$ & & 194.1 & 180.9 & 135.9 & 97.4 & & 209.6 & 186.6 & $145.8 \mathrm{ab}$ & $119.4 \mathrm{ab}$ \\
\hline C. citratus EO $\left(2 \mathrm{dm}^{3} \mathrm{~kg}^{-1}\right)$ & & 198.3 & 185.2 & 145.7 & 98.4 & & 212.9 & 184.7 & $152.6 \mathrm{ab}$ & $122.7 \mathrm{a}$ \\
\hline $0.2 \mathrm{kGy} \gamma$ & & 193.0 & 179.5 & 133.0 & 89.4 & & 204.6 & 163.8 & $163.5 \mathrm{a}$ & $124.7 \mathrm{a}$ \\
\hline $0.4 \mathrm{kGy} \gamma$ & & 193.6 & 180.4 & 135.0 & 95.3 & & 208.9 & 172.5 & $162.1 \mathrm{a}$ & $128.9 \mathrm{a}$ \\
\hline $0.6 \mathrm{kGy} \gamma$ & & 197.4 & 184.9 & 140.2 & 97.4 & & 211.5 & 181.1 & $160.9 \mathrm{a}$ & $131.1 \mathrm{a}$ \\
\hline $0.4 \mathrm{kGy} \gamma+\mathrm{CaCl}_{2}(4 \%)$ & & 195.1 & 182.7 & 139.5 & 96.1 & & 204.8 & 183.9 & $165.3 \mathrm{a}$ & $126.4 \mathrm{a}$ \\
\hline $\begin{array}{l}0.4 \mathrm{kGy} \gamma+ \\
\text { C. citratus } \mathrm{EO}\left(2 \mathrm{dm}^{3} \mathrm{~kg}^{-1}\right)\end{array}$ & & 199.5 & 188.9 & 147.0 & 99.5 & & 216.4 & 179.3 & $171.9 \mathrm{a}$ & $131.0 \mathrm{a}$ \\
\hline
\end{tabular}

Means bearing the same letter/no letters within a column are not significantly different at $p<0.05$

might be attributed to the conversion of organic acids to sugars or to the degradation through respiration (Machado et al., 2015). Doreyappy and Hudder (2001) and Rathore et al. (2007) also reported that acidity variation among different treatments might be attributed to the extent of citric acid degradation as a function of citric acid glyoxylase activity during ripening.

$\mathrm{CaCl}_{2}$ had an effect similar to that recorded for lemongrass oil in controlling TA drops in guava fruits during storage. This result confirms the findings of Mahajan et al. (2011) and Deepthi et al. (2016), who reported a general decline in TA during cold storage of guava fruits and added that the falls were slower in $\mathrm{CaCl}_{2}$-treated fruits compared to the control. TA retention in $\mathrm{CaCl}_{2}$-treated fruits might be due to decreased hydrolysis of organic acids and subsequent accumulation of these acids, which are oxidized at a slower rate because of decreased respiration (Gupta et al., 2011). In other words, it might be due to delayed ripening induced by $\mathrm{CaCl}_{2}$ (Mahmud et al., 2008). On the other hand, irradiating fruits prior to $\mathrm{CaCl}_{2}$ and lemongrass oil treatments was of no use in further retention of TA.

\section{Vitamin $C$}

The results presented in Table 6 show that the ascorbic acid concentration in guava fruits recorded general decreases with the duration of cold storage. The decrements are in agreement with the results reported by Mahajan et al. (2011), Hossain et al. (2014) and Deepthi et al. (2016). In contrast, Razali et al. (2015) and Gil et al. (2006) had reported increases in ascorbic acid content in guava and mango. In this regard, Ibrahim et al. (2014) reported that increases in pineapple vitamin $\mathrm{C}$ at the beginning of the storage period were later followed by decreases. The reductions in ascorbic acid content might be attributable to its susceptibility to oxidative destruction during ripening (Veltman et al., 2000). Lee and Kader (2000) and Singh et al. (2005) reported that the decrease in ascorbic acid content during storage is due to its conversion to an inactive form (dehydroascorbic acid) under the action of ascorbic acid oxidase, and due to the action 


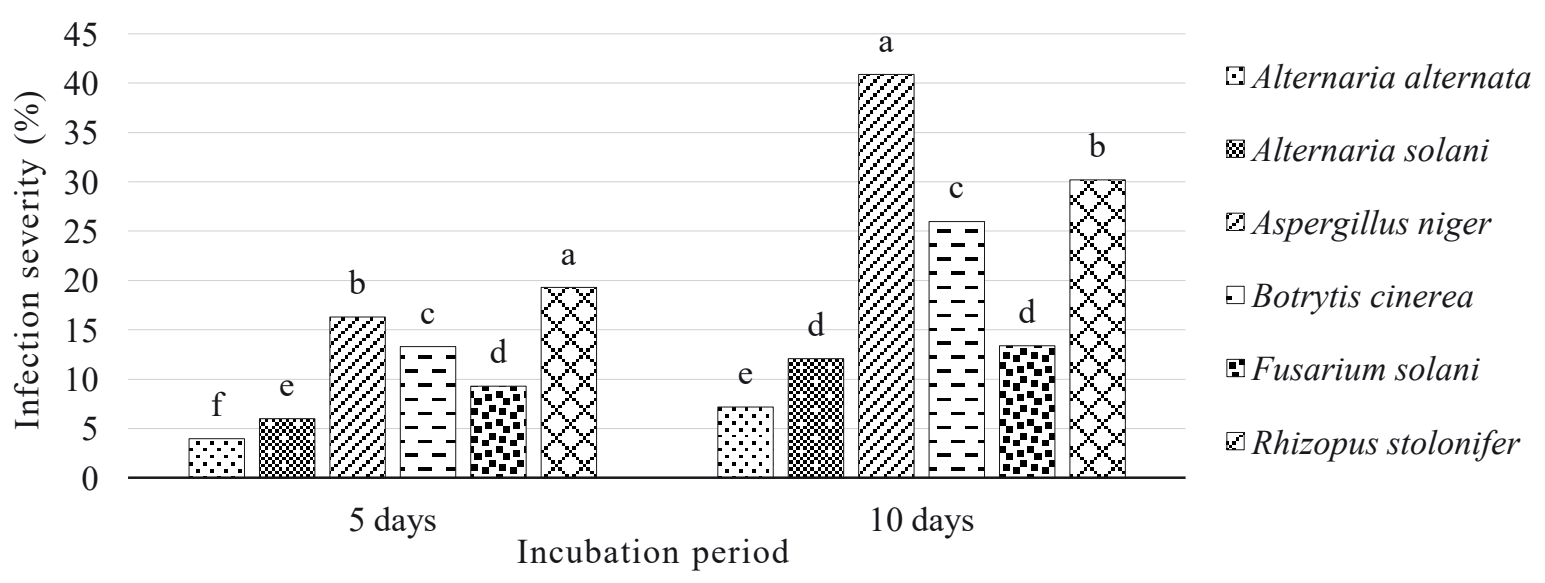

Figure 1. Guava pathogenic fungi infection severity (\%). Bars bearing the same letter in the same group represent values that are not significantly different at $p<0.05$

of other oxidizing enzymes such as peroxidase, catalase and polyphenol oxidase.

In agreement with previously reported results for guava (Hossain et al., 2014; Razali et al., 2015), the investigated irradiation treatments increased the concentration of ascorbic acid in guava fruits compared with non-irradiated fruits. Similar results had been reported by Pandey et al. (2010), who recorded general decrements in guava vitamin $\mathrm{C}$ content after the 8th day in cold storage. In this regard, Razali et al. (2015) reported that UV-C irradiation increased the total antioxidant and total polyphenol contents in guava fruits and attributed that to the activation of a defence mechanism which perceived irradiation as an abiotic stress (Barka et al., 2000). Similarly, $\mathrm{CaCl}_{2}$ treatments resulted in higher ascorbic acid concentrations compared with the control fruits at the end of the storage period. These findings are in agreement with the results reported earlier for guava and apple (Mahajan et al., 2011). Moreover, lemongrass oil treatments also increased vitamin $\mathrm{C}$ concentration in guava fruits. Similar results had been recorded by Geransayeh et al. (2015) when they treated strawberry with thymol EO.

\section{Microbiological studies}

Six different fungal species were isolated from all decayed fruits and were identified as Alternaria alternata, Alternaria solani, Aspergillus niger, Botrytis cinerea, Fusarium solani and Rhizopus stolonifer. The results presented in Figure 1 show that although $A$. niger recorded the most pronounced infection after 10 days of incubation, $R$. stolonifer recorded the severest infection 5 days earlier. All the pathogenic fungi isolated from decayed guava fruits recorded significant differences in infection severity in-between, 5 days after inoculation, with $A$. alternata and $A$. solani displaying the least pronounced infection. At the end of the incubation period, A. alternata and A. solani persisted in recording the lowest infection severity percentage.

Table 7. Guava pathogenic fungi growth inhibition (\%) induced by lemongrass oil

\begin{tabular}{lccccccc}
\hline $\begin{array}{l}\text { C. citratus oil } \\
\text { concentration } \\
\left(\mu \mathrm{g} \mathrm{dm}^{-3}\right)\end{array}$ & $\begin{array}{c}\text { Alternaria } \\
\text { alternata }\end{array}$ & $\begin{array}{c}\text { Alternaria } \\
\text { solani }\end{array}$ & $\begin{array}{c}\text { Aspergillus } \\
\text { niger }\end{array}$ & $\begin{array}{c}\text { Botrytis } \\
\text { cinerea }\end{array}$ & $\begin{array}{c}\text { Fusarium } \\
\text { solani }\end{array}$ & $\begin{array}{l}\text { Rhizopus } \\
\text { stolonifer }\end{array}$ & Mean (B) \\
\hline 0.5 & $12.3 \mathrm{i}$ & $15.7 \mathrm{i}$ & $10.3 \mathrm{i}$ & $17.0 \mathrm{i}$ & $20.3 \mathrm{i}$ & $10.3 \mathrm{i}$ & $14.3 \mathrm{E}$ \\
1.0 & $35.7 \mathrm{~h}$ & $39.7 \mathrm{~h}$ & $40.7 \mathrm{~h}$ & $60.0 \mathrm{~g}$ & $44.7 \mathrm{~h}$ & $44.7 \mathrm{~h}$ & $44.3 \mathrm{D}$ \\
1.5 & $60.3 \mathrm{~g}$ & $68.7 \mathrm{efg}$ & $64.3 \mathrm{fg}$ & $85.0 \mathrm{bc}$ & $60.3 \mathrm{~g}$ & $80.0 \mathrm{cde}$ & $69.8 \mathrm{C}$ \\
2.0 & $85.7 \mathrm{bc}$ & $91.3 \mathrm{abc}$ & $80.3 \mathrm{~cd}$ & $100.0 \mathrm{a}$ & $72.0 \mathrm{def}$ & $100.0 \mathrm{a}$ & $88.2 \mathrm{~B}$ \\
2.5 & $100.0 \mathrm{a}$ & $100.0 \mathrm{a}$ & $100.0 \mathrm{a}$ & $100.0 \mathrm{a}$ & $81.3 \mathrm{bcd}$ & $100.0 \mathrm{a}$ & $96.9 \mathrm{~A}$ \\
3.0 & $100.0 \mathrm{a}$ & $100.0 \mathrm{a}$ & $100.0 \mathrm{a}$ & $100.0 \mathrm{a}$ & $85.6 \mathrm{bc}$ & $100.0 \mathrm{a}$ & $97.6 \mathrm{~A}$ \\
3.5 & $100.0 \mathrm{a}$ & $100.0 \mathrm{a}$ & $100.0 \mathrm{a}$ & $100.0 \mathrm{a}$ & $92.7 \mathrm{ab}$ & $100.0 \mathrm{a}$ & $98.8 \mathrm{~A}$ \\
4.0 & $100.0 \mathrm{a}$ & $100.0 \mathrm{a}$ & $100.0 \mathrm{a}$ & $100.0 \mathrm{a}$ & $100.0 \mathrm{a}$ & $100.0 \mathrm{a}$ & $100.0 \mathrm{~A}$ \\
Mean (A) & $74.3 \mathrm{C}$ & $76.9 \mathrm{BC}$ & $74.5 \mathrm{C}$ & $82.8 \mathrm{~A}$ & $69.6 \mathrm{D}$ & $79.4 \mathrm{AB}$ & \\
\hline
\end{tabular}

Means bearing the same letter within a column are not significantly different at $p<0.05$ 
It was also noted that the infection severity percentages for $A$. solani and $F$. solani were not significantly different at the end of the experimental period. Finally, it can be concluded that the A. niger, $R$. stolonifer and $B$. cinerea pathogenic fungi cause the severest symptoms of rotting when inoculated on guava fruits that are stored at $28 \pm 2{ }^{\circ} \mathrm{C}$.

The results displayed in Table 7 show clearly that lemongrass oil is an effective fungal growth inhibitor. Regardless of the fungal pathogen, lemongrass oil concentrations of $2.5,3.0,3.5$ and $4 \mu \mathrm{g} \mathrm{dm}^{-3}$ inhibited fungal growth very effectively compared with the lower concentrations, and total growth inhibition was achieved when the PDA medium was supplemented with a concentration of $4 \mu \mathrm{g} \mathrm{dm}^{-3}$. Generally, greater growth inhibition was correlated with higher lemongrass oil concentrations, and the differences recorded between the concentrations of $0.5,1.0,1.5,2.0$ and $2.5 \mu \mathrm{g} \mathrm{dm}^{-3}$ were statistically significant. On the other hand, regardless of the lemongrass oil concentration used, $B$. cinerea was found to be the most sensitive and $F$. solani to be the most resistant to the inhibitory effect imposed by lemongrass oil. Here it is worth mentioning that (B. cinerea, $R$. stolonifer) and ( $R$. stolonifer, A. solani) and (A. solani, A. niger, A. alternata) did not show significant differences in-between in terms of growth inhibition induced by lemongrass oil. It was also found that supplementing the PDA medium with the concentrations of lemongrass oil of 0.5 or 3.5 or $4.0 \mu \mathrm{g} \mathrm{dm}^{-3}$ resulted in insignificantly different growth inhibition percentages for all the fungi tested at a given concentration.

In this regard, Jhalegar et al. (2015) reported that lemongrass oil did not only delay decay initiation, but also inhibited/decreased overall decay in Kinnow mandarin fruits caused by Penicillium digitatum and $P$. italicum. Moreover, lemongrass oil was reported to exhibit a broad spectrum of fungitoxicity by completely inhibiting the growth of 35, 45, and 47 fungal species at 500, 1000, and 1500 ppm, respectively (Mishra and Dubey 1994). Tzortzakis and Economakis (2007) reported that lemongrass oil significantly reduced subsequent colony development of $B$. cinerea, $R$. stolonifer and $A$. niger, and other fungal pathogens in vitro. This effect was achieved by altering fungal reproduction and growth in different ways. At a concentration of $25 \mathrm{ppm}$, lemongrass oil inhibited up to $70 \%$ of fungal spore production, and at a concentration of $500 \mathrm{ppm}$, it completely retarded fungal sporulation. Moreover, it reduced spore germination and germ tube length of $B$. cinerea and $R$. stolonifer, and its effect in this regard was concentration dependent. However, lemongrass oil (up to $100 \mathrm{ppm}$ ) was found to accelerate spore germination of $A$. niger.

\section{CONCLUSIONS}

1. Despite the beneficial effect of irradiation on coldstored guava fruits in general, coupling it with calcium chloride or lemongrass oil treatments was of no added value.

2. Lemongrass oil and $\mathrm{CaCl}_{2}$ exerted strong inhibitory effects on fungal growth and physiological activity in guava fruits during cold storage.

3. Besides consumer concerns regarding irradiated foodstuffs, there are incentives for further research incorporating widely accepted essential oils and calcium salts rather than irradiation in guava postharvest trials.

\section{FUNDING}

National Center for Radiation Research and Technology, Atomic Energy Authority.

\section{AUTHOR CONTRIBUTIONS}

R.A.H. and E.A.S. initiated the idea and E.A.S. solely conducted the microbiological experimental work; R.A.H., E.A.S. and A.A.Z. collaborated in conducting physiochemical determinations and finally, R.A.H. and A.A.Z. performed results statistical analysis and A.A.Z. wrote the manuscript.

\section{CONFLICT OF INTEREST}

Authors declare no conflict of interest.

\section{REFERENCES}

AbdAlla M.A., El-Sayed H.Z., El-Mohamedy R.S., 2008. Control of Rhizopus rot disease of apricot fruits (Prunus armeniaca L.) by some plant volatiles aldehydes. Res. J. Agr. Biol. Sci. 4, 424-433.

Abd El-Monem E.A.A., Zahran A.A., Shaban A.E., 2013. Role of some postharvest treatments in maintaining mango fruit quality during cold storage. J. Appl. Sci. Res. 9, 2355-2366.

Adamu S., Bukar A., Mukhtar M.D., 2009. Isolation map and identification of postharvest spoilage fungi associated with sweet oranges (Citrus sinensis) traded in Kano Metropolis. J. Pure Appl. Sci. 2, 122-124.

Akhtar A., Abbasi N.A., Hussain A., 2010. Effect of calcium chloride treatments on quality characteristics of loquat fruit during storage. Pakistan J. Bot. 42, 181188. 
Alves R.E., Filgueiras H.A.C., Almeida A.S., Pereira M.E.C., Cocozza F.M., Jorge J.T., 2004. Postharvest ripening of 'Tommy Atkins' mangoes on two maturation stages treated with 1-MCP. Acta Hortic. 645, 627-632.

Antunes M.D.C., Cavaco A.M., 2010. The use of essential oils for postharvest decay control. A review. Flavour Fragr. J. 25, 351-366.

AOAC, 1990. Official Methods of Analysis. $15^{\text {th }} \mathrm{ed}$. Association of Official Analytical Chemists, Arlington, VA.

AOAC, 2003. Official methods of analysis. $17^{\text {th }}$ ed. Association of Official Analytical Chemists, Arlington, VA.

Balali G.R., Neate S.M., Scott E.S., WhissonD.L., WiCKS T.J., 1995. Anastomosis group and pathogenicity of isolates of Rhizoctonia solani from potato crops in South Australia. Plant Pathol. 44, 1050-1057.

BALL J.A., 1997. Evaluation of two lipid-based edible coatings for their ability to preserve post harvest quality of green bell peppers. M.Sc. thesis, Faculty of the Virginia Polytechnic Institute and State University, USA, 97.

Barka E.A., Kalantari S., Makhlouf J., Arul J., 2000. Effects of UV-C irradiation on lipid peroxidation markers during ripening of tomato (Lycopersicon esculentum L.) fruits. Aust. J. Plant Physiol. 27, 147-152.

Воотн C., 1977. Fusarium: Laboratory guide to the identification of the major species. Commonwealth Mycological Institute, Kew, Surrey, UK.

Bron I.U., Ribeiro R.V., Cavalini F.C., Jacomino A.P., Trevisan M.J., 2005. Temperature related changes in respiration and $\mathrm{Q}_{10}$ coefficient of guava. Sci. Agricola. 62, 458-463.

BURT S., 2004. Essential oils: their antibacterial properties and potential application in foods - a review. Int. J. Food Microbiol. 94, 223- 253.

Carlson L.H.C., Machad C.B.S., Pereira L.K., Bolzan A., 2001. Extraction of lemongrass essential oil with dense carbon dioxide. J. Supercrit. Fluid. 21, 33-39.

Celestino D.V., Sotelo H.R., Pastrana D.M.R. Barrios M.E.V., Silva E.M.M., 2016. Effects of waxing, microperforated polyethylene bag, 1-methylcyclopropene and nitric oxide on firmness and shrivel and weight loss of 'Manila' mango fruit during ripening. Postharv. Biol. Technol. 111, 398405.

Cruz A.F., Medeiros N.L., Benedet G.L., Araújo M.B., Uesugi C.H., Ferreira M.A.S.V., Peixoto J.R., Blum L.E.B., 2015. Control of post-harvest anthracnose infection in guava (Psidium guajava) fruits with phosphites, calcium chloride, acetyl salicylic acid, hot water, and 1-MCP. Hortic. Environ. Biotechnol. $56,330-340$.
Deepthi V.P., Sekhar R.C., Srihari D., Sankar A.S., 2016. Guava fruit quality and storability as influenced by harvest maturity and postharvest application of calcium salts. Plant Archives 16, 174-182.

Domsch K.H., Gams W., Anderson T.H., 1980. Compendium of Soil Fungi. Academic Press, London, UK.

Doreyappy G., Hudder A.G., 2001. Studies on ripening changes in Mango (Mangifera indica L.) fruits. J. Food Sci. Tech. Mys. 38, 135-137.

Garcia R., Alves E.S.S., Santos M.P., Aquije G.M.F.V., Fernandes A.A.R., Santos R.B.D., Ventura J.A., FERNANDES P.M.B., 2008. Antimicrobial activity and potential use of monoterpenes as tropical fruits preservatives. Braz. J. Microbiol. 39, 163-168.

Geransayeh M., Sepahvand S., Abdossi V., Nezhad R.A., 2015. Effect of thymol treatment on decay, postharvest life and quality of strawberry (Fragaria ananassa) Fruit cv. 'Gaviota'. Int. J. Agron. Agr. Res. 6, 151-162.

Gil M.I., Aguayo E., Kader A.A., 2006. Quality changes and nutrient retention in fresh-cut versus whole fruits during storage. J. Agr. Food Chem. 54, 4284-4296.

Gupta N., Jawandha S.K., GiLl S.P., 2011. Effect of calcium on cold storage and post cold storage quality of peach. J. Food Sci. Technol. 48, 225-229.

Hiwale S.S., Singh S.P., 2003. Prolonging shelf life of guava (Psidium guajava L.). Indian J. Hort. 60, 1-9.

Hossain F., Parvez A.K., Munshi M.K., Khalil I., Huque R., 2014. Effect of radiation and chemical treatments on guava (Psidium guajava L.) to delay ripening in relation to organoleptic biochemical and microbiological properties. Int. J. Curr. Microbiol. Appl. Sci. 3, 19-36.

Ibrahim S.M., Nahar S., Islam J.M.M., Islam M., Hoque M.M., Huque R., Khan M.A., 2014. Effect of low molecular weight chitosan coating on physicochemical properties and shelf life extension of pineapple (Ananas sativus). J. Forest Prod. Ind. 3, 161-166.

Inouye S., Tsuruoka T., Watanabe M., Takeo K., Akao M., Nishiyama Y., Yamaguchi H., 2000. Inhibitory effect of essential oils on apical growth of Aspergillus fumigatus by vapour contact. Mycoses. 43, 17-23.

Jhalegar M.D.J., Sharma R.R., Singh D., 2015. In vitro and in vivo activity of essential oils against major postharvest pathogens of Kinnow (Citrus nobilis $\times$ C. deliciosa) mandarin. J. Food Sci. Technol. 52, 22292237.

Jovyn K.T.N., Schröder R., Brummell D.A., Sutherland P.W., Hallett I.C., Smith B.G., Melton L.D., Johnstond J.W., 2015 Lower cell wall pectin solubilisation and galactose loss during early fruit development in apple (Malus $x$ domestica) cultivar 'Scifresh' are associated with slower softening rate. J. Plant Physiol. 176, 129-137. 
LEE S.K., Kader A.A., 2000. Preharvest and postharvest factors influencing vitamin $\mathrm{C}$ content of horticulture crops. Postharv. Biol. Technol. 20, 207-220.

Lester G.E., GrusaK M.A., 2004. Postharvest application of calcium and magnesium to honeydew and netted muskmelons: Effects on tissue ion concentrations, quality and senescence. J. Am. Soc. Hortic. Sci. 124, 545-552.

Lionetti V., Francocci F.F., Ferrari S., Volpi C., Bellincampi D., Galletti R., D’Ovidio R., De Lorenzo G., Cervone F., 2010. Engineering the cell wall by reducing de-methyl-esterified homogalacturonan improves saccharification of plant tissues for bioconversion. Proc. Natl. Acad. Sci. USA, 107, 616-621.

Machado F.L. De C., Cajazeira J.P., João P., Costa J.M.C. DA, 2015. Color change and quality response of 'lane late' orange submitted to degreening process. Engenharia Agrícola, 35, 144-153.

Mahajan B.V.C., GHuman B.S., Bons H.K., 2011. Effect of postharvest treatments of calcium chloride and gibberellic acid on storage behaviour and quality of guava fruits. J. Hort. Sci. Ornamental Plants 3, 38-42.

Mahajan B.V.C., Sharma S.R., Dhall R.K., 2009. Optimization of storage temperature for maintaining quality of guava. J. Food Sci. Tech. Mys. 46, 604-605.

Mahmud T.M.M., Raqeeb A.A., Omar S.R.R., ZaKi A.R.M., AbDUl-Rahman A., 2008. Effects of different concentrations and applications of calcium on storage life and physicochemical characteristics of Papaya (Carica papaya L.). Am. J. Agr. Biol. Sci. 3, 526-533.

Mishra A.K., DubeY N.K., 1994. Evaluation of some essential oils for their toxicity against fungi causing deterioration of stored food commodities. Appl. Environ. Microbiol. 60, 1101-1105.

Morcos J.F., 1984. Studies on rots of pome fruits in ARE. M.Sc. thesis, Faculty of Agriculture, Cairo University, Egypt, 133.

Moubasher A.H., 1993. Soil fungi in Qatar and other Arab countries. The Centre for Scientific and Applied Research, University of Qatar, Doha, Qatar.

Munoz P.H., Almenar E., Valle V.D., Velez D., GAVARA R., 2008. Effect of chitosan coating combined with postharvest calcium treatment on strawberry (Fragaria ananassa) quality during refrigerated storage. Food Chem. 110, 428- 435.

NEGI S.S., RAJAN S., 2007. Improvement of guava through breeding. Acta Hortic. 735, 31-37.

Orathai W., Lin-Shang K., 2012. The quality maintenance and extending storage life of mango fruit after postharvest treatments. World Acad. Sci. Eng. Technol. 69, 936-941.

Palhano F.L., Vilches T.T.B., Santos R.B., Orlando M.T.D., Ventura J.A., Fernandes P.M.B., 2004. Inactivation of Colletotrichum gloeosporioides spores by high hydrostatic pressure combined with citral or lemongrass essential oil. Int. J. Food Microbiol. 95, 61-66.
Paliyath G., Murr D.P., Handa A.K., Lurie S., 2008. Postharvest biology and technology of fruits, vegetables, and flowers. Wiley-Blackwell, Iowa, USA.

Pandey S.K., Joshua J.E, Bisen, AbHaY., 2010. Influence of gamma-irradiation, growth retardants and coatings on the shelf life of winter guava fruits (Psidium guajava L.). J. Food Sci. Technol. 47, 124-127.

Paviani L., Pergher S.B.C., Dariva C., 2006. Application of molecular sieves in the fractionation of lemongrass oil from high-pressure carbon dioxide extraction. Braz. J. Chem. Eng. 23, 219-222.

Pelczar M.J., 1993. Microbiology. $5^{\text {th }}$ Edition, McGrawHill Inc., USA.

RAPer K.B., Fennell D.I., 1977. The Genus Aspergillus. Robert E. Krieger Publishing Company, Huntington, New York.

Rathore H.A., Masud T., Sammi S., Soomro A.H., 2007. Effect of storage on physico-chemical composition and sensory properties of mango (Mangifera indica L.) variety Dosehari. Pak. J. Nutr. 6, 143-148.

Razali Z., George D.S., Ibrahim N.A.N., 2015. Improvements in quality and antioxidant capacity of guava (Psidium guajava L.) exposed to UV-C irradiation. Proc. $3^{\text {rd }}$ International Conf. on Chemical, Agricultural and Medical Sciences (CAMS-2015), 10 11 December, Singapore, 50-53.

SELVAN M.T., BAL J.S., 2005. Effect of different treatments on the shelf life of 'Sardar' guava during cold storage. J. Res. Punjab Agr. Univ. 42, 28-33.

Serrano M., Romero D.M., Castillo S., Guillen D., VALERO M., 2005. The use of the natural antifungal compounds improves the beneficial effect of MAP in sweet cherry storage. Innov. Food Sci. Emerg. Technol. 6, 115-123.

Shahi S.K., Patra M., Shukla A.C., Dikshit A., 2003. Use of essential oil as botanical-pesticide against postharvest spoilage in Malus pumilo fruits. Biocontrol 48, 223-232.

Silva D.F.P., Salomão L.C.C., Zambolim L., Rocha A., 2012. Use of biofilm in the postharvest conservation of 'Pedro Sato' guava. Rev. Ceres, Viçosa. 59, 305 312.

Singh S., Singh A.K., Joshi H.K., 2005. Prolong storability of Indian gooseberry (Emblica officinalis Gaertn.) under semiarid ecosystem of Gujarat. Indian J. Agr. Sci. 75, 647-650.

Tian J., Ban X.Q., Zeng H., He J.S., Huang B., Wang Y.W., 2011. Chemical composition and antifungal activity of essential oil from Cicuta virosa L. var. latisecta Celak. Int. J. Food Microbiol. 145, 464-470.

Tserennadmid R., Takó M., Galgóczy L., Papp T., Pesti M., Vágvölgyi C.S., Almássy K., Krisch J., 2011. Anti-yeast activities of some essential oils in growth medium, fruit juices and milk. Int. J. Food Microbiol. 144, 480-486.

Tyagi A.K., Malik A., 2010. Liquid and vapour-phase antifungal activities of selected essential oils against Candida albicans: microscopic observations and 
chemical characterization of Cymbopogon citratus. BMC Complement. Alternative Med. 10, 1-11.

Tzortzakis N.G., Economakis C.D., 2007. Antifungal activity of lemongrass (Cymbopogon citratus L.) essential oil against key postharvest pathogens. Innov. Food Sci. Emerg. Technol. 8, 253-258.

Valenzuela J.L., Manzano S., Palma F., Carvajal F., Garrido D., Jamilena M., 2017. Oxidative stress associated with chilling injury in immature fruit: Postharvest technological and biotechnological solutions. Int. J. Mol. Sci. 18, 1467-1492.

Veltman R.H., Kho R.M., Schaik van. A.C.R., SAnders M.G., OOSTERhaVen J., 2000. Ascorbic acid and tissue browning in pears (Pyrus communis L. cvs Rocha and Conference) under controlled atmosphere conditions. Postharv. Biol. Technol. 19, 129-137.
Vicente A.R., Manganaris G.A., Sozzi G.O., Crisosto C.H., 2009. Nutritional quality of fruits and vegetables. In: Postharvest Handling: A Systems Approach. W.J. Florkowski, R.L. Shewfelt, B. Brueckner, S.E. Prussia (Eds), Elsevier Inc.Academic Press, San Diego, 57-106.

Yonemoto Y., Higuchi H., Kitano Y., 2002. Effects of storage temperature and wax coating on ethylene production, respiration and shelf-life in cherimoya fruit. J. Jpn. Soc. Hort. Sci. 71, 643-650.

Zhong Q.P., XIA W.S., 2007. Effect of 1-methylcyclopropene and/or chitosan coating treatments on storage life and quality maintenance of Indian jujube fruit. LWT-Food Sci. Technol. 40, 404-411.

Received July 24, 2017; accepted December 20, 2017 